\title{
Reformation and transformation today: Essentials of reformation tradition and theology as seen from the perspectives of the South
}

\begin{tabular}{|c|c|}
\hline \multicolumn{2}{|l|}{$\begin{array}{l}\text { Author: } \\
\text { Jerry Pillay }{ }^{1}\end{array}$} \\
\hline \multicolumn{2}{|c|}{$\begin{array}{l}\text { Affiliation: } \\
{ }^{1} \text { Department of Church } \\
\text { History and Church Polity, } \\
\text { Faculty of Theology, } \\
\text { University of Pretoria, } \\
\text { South Africa }\end{array}$} \\
\hline \multicolumn{2}{|c|}{$\begin{array}{l}\text { Research Project Registration } \\
\text { Project Leader: J. Pillay } \\
\text { Project Number: } 04653484\end{array}$} \\
\hline \multicolumn{2}{|c|}{$\begin{array}{l}\text { This research is part of the } \\
\text { project, 'African Christianity } \\
\text { and Development', directed } \\
\text { by Prof. Dr Jerry Pillay, } \\
\text { Department of Church } \\
\text { History and Church Polity, } \\
\text { Faculty of Theology, } \\
\text { University of Pretoria. }\end{array}$} \\
\hline \multicolumn{2}{|c|}{$\begin{array}{l}\text { Corresponding author: } \\
\text { Jerry Pillay, } \\
\text { jerry.pillay@up.ac.za }\end{array}$} \\
\hline \multicolumn{2}{|c|}{$\begin{array}{l}\text { Dates: } \\
\text { Received: } 13 \text { Sept. } 2017 \\
\text { Accepted: } 14 \text { Sept. } 2017 \\
\text { Published: } 31 \text { Oct. } 2017\end{array}$} \\
\hline \multicolumn{2}{|c|}{$\begin{array}{l}\text { How to cite this article: } \\
\text { Pillay, J., 2017, 'Reformation } \\
\text { and transformation today: } \\
\text { Essentials of reformation } \\
\text { tradition and theology as } \\
\text { seen from the perspectives of } \\
\text { the South', HTS Teologiese } \\
\text { Studies/Theological Studies } \\
73(3) \text {, a4815. https://doi. } \\
\text { org/10.4102/hts.v73i3.4815 }\end{array}$} \\
\hline \multicolumn{2}{|c|}{$\begin{array}{l}\text { Copyright: } \\
\text { (C) 2017. The Authors. } \\
\text { Licensee: AOSIS. This work } \\
\text { is licensed under the } \\
\text { Creative Commons } \\
\text { Attribution License. }\end{array}$} \\
\hline \multicolumn{2}{|l|}{ Read online: } \\
\hline 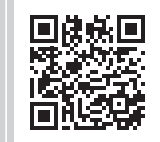 & $\begin{array}{l}\text { Scan this QR } \\
\text { code with your } \\
\text { smart phone or } \\
\text { mobile device } \\
\text { to read online. }\end{array}$ \\
\hline
\end{tabular}

\begin{abstract}
The Protestant Reformation is one of the greatest turning points in the history of Christianity. In some senses, it is described as a 'theological revolution' which led to the emergence of the Protestant movement and the separation of the Church. This research explores some of the theological themes that became the turning point of Christianity. These themes are sola scriptura, sola fide, sola gratia, solus Christus and Soli Deo Gloria. This article attempts to briefly explore these essential theological principles of the Reformation and assess its relevance for today in light of new realities, encounters and theological developments. It pays particular attention to the realities of the Global South, mainly South Africa, and shows how these can form a basis for renewal and transformation of Reformed theology and practice today. In this sense, the article establishes that the 'theological revolution' continues into the 21st century bringing about ecclesiastical, social and cultural change.
\end{abstract}

\section{Introduction}

There are many turning points in the history of Christianity. Mark Noll (2012) in his book Turning Points: Decisive Moments in the History of Christianity discusses at least 14 such great moments. Donald McKim in his book Theological Turning Points (1973) traces some of the key theological turning points in the Christian church by discussing certain theological themes and how these have evolved from the time of the Early Church to now. In this article, I shall restrict my focus to the Reformation period as a decisive moment for the history of Christianity, largely because 2017 is the 500th celebration of the Martin Luther Reformation. Moreover, I shall explore the theological turning points ${ }^{1}$ emerging from the Reformation and its relevance in the African context today.

The 16th-century Protestant Reformation is one of the greatest turning points in the history of Christianity. In some senses, it is described as a 'theological revolution' which led to the emergence of the Protestant movement and the separation of the Church (Oberman 2004:201). Martin Luther's refusal in October 1518 to recant views expressed in his 95 Thesis (1517) was repeated 6 months later in his act of 'rebellion', this time before the Emperor at Worms - that is, against secular authority as well. The Reformation, therefore, can be seen as a 'revolution' only, and at the very most, with regard to the struggle against the Church embodied in the Papal State, and against the hierarchical Church as the supreme authority and court of appeal in secular as well as religious affairs. Oberman (2004:201) states that the word 'revolution' in this context means insubordination, a brash refusal of obedience to Mother Church, to affirm what the reformers understood to be the true Church (2004:202).

At the heart of the Reformation was the intent to reform, revive and renew the church. Basic for the understanding of ecumenism is that the Reformers did not intend to found a new church but sought reform of the whole church. The Reformation was neither a new religion nor a simple recovery of an older one. It was a revision, not a rejection, of the medieval tradition (Gerrish 1993:1). In the minds of the reformers, the church was not standing up to the realities of its time in confronting financial corruption, sexual immorality and political power. Reformers such as Luther, Calvin, Zwingli, and others called for the 'reawakening' of the Church to address these issues. In so doing, they did not hesitate to point out the inadequacies and corruption of the church which impacted on its life, work, witness and theology. Thus, the 16th-century Protestant Reformation was an attempt to reform and transform both church and society. And, in this sense, it was to have a 'revolutionary' effect. McGrath establishes that the Reformation embraced a 
number of quite distinct, yet overlapping, areas of human activity: the reform of both the morals and structures of church and society, new approaches to political issues, shifts in economics thinking, the renewal of Christian spirituality, and the reform of Christian doctrine (McGrath 2012).

In our day and age, the Christian church is faced with similar challenges and much more as we deal with corruption, political turmoil, poverty, economic injustice, climate change, sexual immorality, secularisation, racism, spiritual apathy, religious factions, violence, the abuse against children and women, migration, refugees, human trafficking, etc. All of these call for a strengthened public witness as we seek to bring about the transformation of church, society and the world. In Reformed theology, the five solas paved the way for radical revolutionary theological thinking: solus Christus, sola scriptura, sola fide, sola gratia and soli Deo Gloria. How do these essentials of the Reformation hold true for us today in living out our faith and transforming society?

Charged with unfaithfulness to tradition, John Calvin (15091564) replied that the constant endeavour of the reformers was not just to transmit the tradition faithfully but to put it in the form they thought would prove best (Gerrish 1993:1). The continuing vigour of the old message is perhaps still more convincingly displayed in theologians of our time who have not always echoed the old idiom but have understood how to apply and develop its content in fresh ways. This article attempts to briefly explore some of the essential theological principles of the Reformation and assess its relevance for today in the light of new realities, encounters and theological developments. It pays particular attention to the realities of the Global South, mainly Africa, and shows how these can form a basis for renewal and transformation of Reformed theology and practice, as we continue the Reformation.

We shall now look at the main theological contributions of the Reformation bearing in mind that the five solas are interpreting each other interactively (Kortner in BosserHuber 2015:51). None of them may be considered independently.

\section{Sola scriptura}

At the heart of the Reformation was the quest to return to the Bible. The Reformation saw a new importance being attached to Scripture - or, perhaps, an ancient view of the importance of Scripture being recovered. The idea of sola scriptura, 'by Scripture alone', became one of the great slogans of the reformers as they sought to bring the practices and beliefs of the church back into line with those of the Golden Age of Christianity. According to McGrath (2012), if the doctrine of justification by faith alone was the material principle of the Reformation, the principle of sola scriptura was its formal principle. If the reformers dethroned the pope, they enthroned Scripture. Thus, the issue of authority and scripture became a significant turning point of the Reformation.

Mainstream reformers had no difficulty with the notion of a 'traditional interpretation' of the Bible. In fact, they advocated that they were not attempting to start a new church but were seeking to reform and renew Christianity, which implied affirming continuity with the great historic tradition of Christian faith, stretching back through the patristic era to the apostles themselves.

For example, Calvin asserted that the institutions and regulations of both church and state were required to be grounded in Scripture. Zwingli stated that 'the foundation of our religion is the written word, the Scriptures of God'. Heinrich Bullinger stated that the authority of Scripture was absolute and autonomous: 'Because it is the Word of God, the holy biblical Scripture has adequate standing and credibility in itself and of itself'. Such views indicate the consistently high view of Scripture adopted by the reformers. It represents a major point of continuity with medieval theology. However, the turning point for Luther was the rejection of the claim that the 'Roman Catholic is superior to all others' (McKim 1973:109). Luther claimed that the church was founded on God's Word; this means that all obedience must be given not to the pope or the hierarchy but to Christ who heads the church. For Calvin, Holy Scripture is God's revelation. It is the 'Word of God' (Inst 1.7.1) established by the work of the Holy Spirit. Calvin, like Luther, rejected Roman Catholic claims about the authority of the church and the primacy of the pope. Calvin was willing to call Peter 'the first of all believers' but refused to deduce from this primacy over others.

The difference between the reformers and medieval theology at this point concerns how Scripture is defined and interpreted, rather than the status that it is given. It is this interpretation of Scripture in a changing world that becomes a crucial element for renewal and transformation. It is a stark reminder that the Reformation cannot only be discussed in terms of its ecclesial meaning but also in its relation to culture as a whole. The issue of context and biblical interpretation becomes a serious matter of importance.

The Bible is a central document of western civilisation, not only as the source of Christian ideas but also as an influence upon education and culture. Today this is being seriously challenged as we question the 'hermeneutical lens' we tend to use in interpreting Scripture. Furthermore, the critical question is 'Who is interpreting Scripture and for whom?' Gonzalez points out that the old map of Christianity on which we operated a few decades ago is no longer operational, and a new consciousness requires a new map that is polycentric which goes beyond North Atlantic-Europe and North America (Gonzalez 2002:9-13). Peel (2006) states that the Bible has been:

used to legitimise doctrine and witness that with hindsight we now all recognised as sub-Christian. From apartheid and racism to slavery and sexism, from burning scientists at the stake to driving indigenous people off their lands, from ruthlessly raping the natural world to justifying minors working twelve hours per day in mines, the scale of misery, abuse and inhumanity which has been perpetuated by biblical authorisation has beggared belief. (p. 13) 
Gerald West (2009), speaking into the South African context, makes the point that the Bible has always been at the centre of the liberation struggle even though it has been categorised as a tool of oppression. For example, it was used as the tool to build an apartheid South Africa and equally, it was used as the key text of the struggling masses in South Africa for liberation and justice.

It is important to note that the ideological equation of the Bible with the Word of God has been seriously challenged by many scholars. Tinyiko Maluleke (1996), for example, states the following:

I propose that the equation of the Bible with the 'Word of God' is not only naïve but it is a dangerous form of naïveté. Furthermore, I propose that this equation has been and will continue to be more debilitating for Black African theologies than any of the dangers highlighted by Bediako, Sanneh and Mugambi combined. The equation of colonialism with Christianity if and where it has occurred, has done far less harm to Black and African theologies than the equation of the Bible with the Word of God. (p. 12)

The above points establish the need for Reformed theology to seek renewal and transformation in the area of further understanding sola scriptura, the focus is not only on what the interpretation is but, more significantly, on who is interpreting. The reformed faith has the obligation of protecting the text from being co-opted by the powerful and the elite and, thereby, giving vent and expression to the 'voice' of the poor, marginalised and oppressed masses - the people from below. How do the latter groups inform biblical interpretation? How can this become a source for renewal and transformation? In the context of the Global South critical biblical interpretation and application of scripture has become the norm. Whilst Reformed theology and tradition has taught us to do this, contextual realties aligned to the quest for justice and peace has taken it even further. The rise of Liberation, Black and African theologies has help shed new light on biblical interpretation and understanding today. Perhaps these theologies would help steer and stir the continuity of the reformation - through the lens of African Christianity and interpretation.

\section{Sola fide}

Essential to the Reformation is the doctrine of justification by faith alone: Sola Fide. The theme of 'redemption through Christ' is central throughout the New Testament, Christian worship and Christian Theology. The term 'soteriology' is used in Christian theology to communicate the images which describes the redemption achieved through the death and resurrection of Christ. McGrath (2012) points out that there are five broad components to this network of ideas: Images of victory, Images of a changed legal status, Images of changed personal relationships, Images of liberation and Images of restoration to wholeness. All of these images, no doubt, describe renewal and transformation.
It is not my intention here to get stuck in the theological debates of the Doctrine of Justification by Faith. ${ }^{2}$ My point of entry into this discussion is to mention that this doctrine provided another theological turning point in history. The redemption of Christ through the cross and resurrection provides the basis for renewal and transformation. It is through this act that God in Christ makes all things new. Solus Christus became the new theological focus of the reformation and with this the emphasis that one is saved 'by faith alone' (in Christ). It put into question, and perhaps serious confrontation, the teaching of salvation by works. Luther's focus on the teologiacrucis makes this point abundantly clear. Salvation by faith became a significant turning point in the theology and history of the church. This new found theological emphasis was to impact not only the church but society at large.

The new theological emphasis on individual faith also contributed to the growing influence of the new individualistic philosophy. The basic tenet of Protestantism was the doctrine that human beings were justified by faith rather than by works. Each person had to search his or her own heart to discover if acts stemmed from a pure heart and faith in God. Unfortunately, the new theological focus on individual faith was to strongly influence the economic views of the new middle-class artisans and small merchants. Such people felt quite genuinely and strongly that their economic practices, though they might conflict with the traditional law of the old church, were not offensive to God. On the contrary: they glorified God.

The new doctrines stressed the necessity of doing well at one's earthly calling as the best way to please God, and emphasised diligence and hard work. These doctrines subsequently led to the spiritualising of economic processes and the belief that 'God instituted the market and exchange' (Pillay 2002:79). This emphasis, however, sadly took the Christian focus away from the general concern for the community and the obligation to the poor. It gave acceptance to the liberal paradigm: poverty as backwardness, stressing that the poor should be enabled to reach their full potential.

Although this view on poverty has been seriously debated and challenged over the years, we still need to assess how the Reformation relates to imperial capitalism and to the male means-end rationality in science, technology and individualistic calculating mentality (Duchrow \& Hoffmann 2015:20). How does this view of sola fide stand in need of renewal and reformation is a question we must continue to engage, especially when it is used as a theological justification to support economic systems that oppress others, as in the case of Africa. One of the theological miracles of the late 20th century is the rediscovery of the biblical witness to God's particular concern for the poor and oppressed (Pillay 2002:129).

2.It is interesting to note that the Roman Catholic Church, Lutheran World Federation World Methodist Conference and the World Communion of Reformed Churches World Methodist Conference and the World Communion of Reformed Churches
have all signed the Joint Declaration on the Doctrine of Justification by Faith (JDDJ), in which they all agree that they have more in common than what divides them. 
The link between faith and reality can be a basis for continuing the Reformation as we continue to explore 'unfinished' aspects of the Reformation in relation to church and society. John de Gruchy affirms this by stating that Reformed theology has an alternative by seeking to creatively retrieve theology in the interest of social justice (De Gruchy 1991). He establishes that in the South African context, given the history of apartheid, theology cannot be done in a vacuum; social transformation requires the reinterpretation of 'the significant symbols that people have inherited' so that these can become 'sources for a new social imagination and guides for a new kind of social involvement'(ibid). He adds further that theologically most important is the strong prophetic and liberating trajectory within the reformed heritage which encourages socio-economic transformation. Reformed theology thus, has the task of understanding faith in the context of community and life experiences.

\section{Soli Deo Gloria: Sovereignty of God}

John Calvin's theology took the believer's responsibility in the world more seriously than Luther. His view on the sovereignty of God gave rise to the idea of mission as 'extending the reign of Christ' both by inward spiritual renewal of individuals and by transforming the face of the earth through filling it with 'the knowledge of the Lord'. This particular view led Calvin into bringing about social transformation in Geneva.

It stressed the point of covenantal theology and laboured the fact that God covenants with all human beings and they are part of the human chain. Calvin employed the traditional organic metaphor for society (as found in Ac 2:42ff), in which, as he wrote, no member has 'power for itself nor applies it to its own private use, but each pours it out to the fellow members'; what chiefly matters is 'the common advantage of the whole body' (Inst 111, vii, 5). Occasionally he identified this community with the whole human race. 'All people', he could maintain, 'are bound together as a sacred chain ... [which] ... should be embraced in one feeling of love' (Commentary Ac 13:36; Inst 11, viii, 55).

Consequently, it is not surprising that Calvin, like Luther, showed a particular concern for the poor which resulted in his attempt to transform his society, especially in Geneva. He concerned himself with the issues of commerce and economic justice. His theology was not disembodied, divorced from the realities of life where labourers and employers are often at odds over economic matters. Calvin realised that because of the nature of humanity and the sinfulness of all of our institutions, our endeavours are to some extent motivated by self-interest, pride, and greed. Yet, his is a 'world-affirming theology' in the sense that he sought to apply the gospel to all of life. For him, that meant seeking the guidance of Scripture for the problems besetting humanity, particularly those besetting the citizens of Geneva.

Thus, Calvin as a theologian and pastor became involved in everyday matters as diverse as the high cost of dying, hospitals, sumptuary laws, and the regulation of business and industry and the question of wages. Calvin and Farrell instituted the first free public education for both sexes. Beyond the welfare system and education, the work of Calvin and the pastors reached out to suggestions for railings to protect children on stairs and balconies. Fires and chimneys were regulated and efforts were made to clean the town and to repair streets. Regulation of prices for the necessities of life was an accepted principle of the early Reformation in Geneva. Some today may not agree with or approve of Calvin's stands, but they must admit that he regarded no area as too secular to be of legitimate Christian concern. The reformers generally advocated an involvement with the world. However, unlike the Middle Ages, they went a step further to attempt to transform society (Pillay 2002).

For example, Luther formulated new social policies to deal with major economic and social change. Luther and his colleague Karlstadt made provision in Wittenberg for the city council to provide low-interest loans for workers, subsidies for education and training for the children of poor, taxes to support the poor - all designed to prevent and alleviate poverty. In 5 years they changed the theory and practice of poor relief which had been established by centuries of ecclesiastical tradition. They were convinced that fundamental human rights of equality, freedom and brotherly love had their source in the Christian faith. However, Luther also believed that this task of social change was essentially a task for the secular ruler and kingdom to carry out. This was the birth of the two 'kingdoms' theory. Luther introduced two authorities (i.e. 'kingdoms'): spiritual, and civil justice and order. Both are ordained by God as forces to combat the empire of Satan. Christians are subject to both authorities; firstly, however, to the spiritual authority and because they are subject to both authorities, Christians cannot live exclusively in either the spiritual 'kingdom' or the civil 'kingdom'. This theory strengthened the separation of state and church. Although Calvin drew a distinction between state and church, he believed that the function of the state was to serve the divine purpose of God.

Given the dynamics of a world in which the rich get richer and the poor get poorer and the number of people living in poverty and hunger continues to increase, it is important for Reformed theology to make a clear commitment of standing with the poor and oppressed in the world. We need to shift from a 'window-dressing' theological approach to an indepth involvement with the plight of the poor. We need to ask whether our theological positions are life-enhancing and life-affirming; do they follow the Bible in socio-historic precision, in essence, do they contribute to liberation and justice?

For Allan Boesak the issue of justice is crucial; it is part and parcel to the Christian Gospel. In fact, it is the declaration of the Lordship of Jesus Christ. Whenever Christians speak out and act against injustice, inequality and the dehumanisation of the human being, they serve as the ambassadors and 
servants of Christ. Boesak singles out the Belhar Confession (1986) in this respect where it states:

in a world filled with injustice and enmity God in a special way is the God of the destitute, the poor and the wronged ... that the church as God's possession is called to stand where God stands, namely against injustice and with the wronged. (p. 7)

Boesak (2005) points out that this Confession helps us to:

first, stand up (and be counted) for the poor and the destitute and, second, to stand where God stands. Not just in front of, in protection, but alongside, in solidarity of struggle. Not in mere sympathy but in identification with. The church must do that not because it is obsessed with the poor, but as the possession of God, in Whom its grounds of being, its identity is found. (p. 200)

In this sense, we need to explore what reformed churches can contribute to alleviating suffering and to transforming our societies. God created this world and wants to preserve the world until it comes through its end to its future in a 'new heaven and a new earth' ( $\operatorname{Rv} 21: 1-2)$. It is God's will that human life be a life in communion, peace and justice. Reformation tradition and theology must continue to reflect theologically on the global threats to humanity and the Earth - both positively and negatively. We are living in difficult times as we experience climate change and witness the devastation of the earth. Reformed theology must awaken to a renewed sense of responding to our given realities and focus on the need of 'caring for the earth'. This could be a new theological 'turning point' for the church.

The Accra Confession (2004) is a significant attempt in focusing theology on 'covenanting and caring for the earth'. It has outlined and prophetically engaged the issues of economic justice, gender justice and ecological justice. It has rightfully pointed us to these matters and prompted us to respond to the unjust realities of life. It also offers a critique on the Empire and explores its damaging effects in the globalised world. Boesak has offered valuable theological reflection on Empire and establishes that the Christian church today is facing 'a new Rome' (Boesak \& Hansen 2009:59-72). Consequently, he states that the church is called to resist all these new forms of idolatry for they have moral, political, economic and theological consequences. Boesak has unceasingly offered a solid critique on the concept of power from a justice perspective. Justice and peace is the cry of life. The Global South can contribute to this significant theme in constructive and radical ways as we continue the Reformation.

For example, in Africa, we need to ask what value and significance the reformed faith can have in the context of poverty, religious violence, civil factions, political instability and dictatorship. How do these realities impact on the understanding and development of Reformed theology and tradition today? Added to this is the issue of globalisation which has impacted on economic, political, cultural and religious spheres of society. These changes have many consequences. Migration, whether forced or voluntary, changes in family structures, economic, ecological and social pressures have encouraged mobility which has created multiple social and religious identities. We have seen this impact on Europe, especially in the past year. The resurgence of racism and ethnic and religious violence in Africa, US and other countries across the globe is generating real cause for concern and the de-stability of peace. These new realities are changing the world, churches and the way we 'do' theology today. It is changing the landscape of theology and the ecumenical discourse. How can the renewal and transformation of Reformed theology help us with creating a world with harmony and Shalom?

\section{Reformed spirituality}

This also impacts our understanding of reformed spirituality. Spirituality is the pattern by which we shape our lives in response to our experiences of God as a very real presence in and around us. To be spiritual is to take seriously our consciousness of God's presence and to live in such a way that the presence of God is central in all that we do. Such spirituality turns to the world, not away from it. It gives attention to the threats of life and embraces the need for justice.

Reformed spirituality is geared towards equipping lifegiving transformative engagement in the world. It is a spirituality that is built in community and builds community. Thus, any piety that appears to be content with a personal relationship with Jesus, and which shuns or belittles the horizontal dimension of discipleship, is suspect. Any spirituality that advocates a withdrawal from what is going on in the world is contrary to Christ's spirit. This is precisely what the reformers have taught us - no doubt, a turning point in history and theology.

This concept of spirituality aligns well with the African concept of Ubuntu which says that 'I am because of you. I belong therefore I am'. This concept of community is what shapes spirituality and life. For the Africans, life is not compartmentalised but integrated into a holistic experience in which culture, politics, economics, religion and the earth is all deeply interconnected. Spirituality is not divorced from the realities of life. This essential teaching of the Reformation has a great sense of resonance within the African context. Unlike the Western world where secularisation seems to be the growing influence, in the Global South spirituality, is still seen as an integral part of life. It is thus not surprising that the Global South is or becoming the new centre of Christianity (Van Beek 2009:vii).

\section{Sola Gratia}

At the centre of Reformed theology is the message of sola gratia, another theological turning point. It reminds us that grace alone is the source and sustenance of our salvation. God's provision of saving, sustaining and glorifying grace is the golden thread uniting all Christian scripture and enabling all Christian faithfulness. This means all works honouring God - including our personal sanctification, our love for neighbours and enemies, our zeal for world mission, our free 
offer of the Gospel, our warnings of judgement, our promises of eternity, our mercy toward the poor and oppressed, our stewardship of God's world, our battles against Satan, our prayer for God's blessing, and our work toward Christ's coming - all find proper motivation and enablement in love for Christ. Of course, this can be misused to use grace to excuse sin, but the principles of grace revealed in all Scripture are the fuel of personal holiness and spiritual revival for those led by the Spirit.

Thus, presenting the doctrines of grace in a warm and embracing way is not to obscure holy boldness but to encourage compassion and humility in the face of God's sovereign mercy to all he loves from every tribe, language, people and nation. As the kindness of God has led to repentance and renewal among us, we must be committed to a manner and ministry that reflects God's grace to others (cf. Rm 2:4; $1 \mathrm{Pt}$ 3:15). We must be on guard that the grace message that God has brought to us (or our particular expression of it) does not become a jewel that we admire and adore for the joy it brings us rather than for the hope it offers the world.

The critical question is: How do we understand this concept of grace in light of the new emerging world experiences impinging on the role of women in society, issues of human sexuality, religious intolerance and violence, racism, xenophobia, tribalism, the refugee situation, etc.? How do we express grace and hospitality to differing views, theological beliefs and human experiences? All of these impress upon us the need for renewal and transformation as we seek to build inclusive communities and foster better relationships with people of other faiths. These are realities that Reformed theology and public witness would have to deal with, and it is these that would hopefully continue the reformation and bring theological revolutionary ideas encouraging hospitality, grace and love to all people on earth.

How does the concept of grace foster Christian unity rather than perpetuate divisions? The reformed understanding of grace is an essential teaching that should enable us to cross boundaries and barriers of cultural, racial, economic, ethnic and religious divides. This is precisely what is needed to face the current realities of the world and divisions in the church. As Dirk Smith puts it, 'we do not live in a time of unity', many people in church and society would probably say that unity is no longer necessary or possible (Smith 2007:275). Reformed theology thus has an obligation to hold both unity and justice together. Grace (sola gratia) is an essential principle for inclusivity, humility, unity and peace.

\section{Conclusion}

In this article, I have referred to the Reformation as a significant 'turning point' in history. I have taken the essential theological themes from the Reformation and explored its continued impact on the Global South and what the Reformation may continue to mean in this context. Moltmann (in Willis \& Welker 1999, p 120) states that Reformed theology is reforming theology. It owes its existence to the unique Reformation of the 16th century, but it is more than a historical memory and also something other than a historical commitment (in Willis \& Welker 1999:120-122). It is concerned with the Reformation of the whole life and of the world. As the world is still not what God intended and wills it to be, in this sense, the Reformation continues. It may take insubordination to the Empire and powers that be in order to be obedient to God. This is a call for radical Reformation and, maybe, a theological revolution that calls for justice for the poor and care for the earth. The reformed church is reforming: may the Reformation continue!

\section{Acknowledgements Competing interests}

The author declares that he has no financial or personal relationships which may have inappropriately influenced him in writing this article

\section{References}

Boesak, A., 2005, The tenderness of conscience - African renaissance and the spirituality of politics, Sun Press, Stellenbosch.

Boesak, A. \& Hansen, L., 2009. Globalisation - The politics of empire, justice and the life of faith, Sun Press, Stellenbosch.

De Gruchy, J., 1991, Liberating reformed theology: A South African contribution to an ecumenical debate, Wm. B. Eerdmans Publishing Co, Grand Rapids, MI.

Duchrow, U. \& Hoffmann, M., 2015, Politics and economics of liberation, Lit Verlag Dr W. Hopf, Berlin.

Gerrish, B.A., 1993, Continuing the reformation: Essays on modern religious thought, The University of Chicago Press, Chicago, IL.

Gonzalez, J.L., 2002, The changing shape of Church history, Chalice Press, St Louis, MO.

Kortner, U.H., 2015, 'An exclusive faith: The fourfold "Alone" of reformation theology', in F. Bosse-Huber, Gundlach \& Locher (ed.), Reformation legacy and future, pp. 50-65, World Council of Churches Publication, Geneva.

McGrath, A.E., 2012, Reformation thought an introduction, Wiley-Blackwell, Malden, MA.

McKim, D.K., 1973, Theological turning points: Major issues in Christian thought, John Knox Press, Louisville, KY.

Moltmann, J., 1999, 'Theologia Reformata et Semper Reformanda', in D. Willis \& M. Welker (eds.), Toward the future of reformed theology: Tasks, topics, traditions, pp. 120-135, William B. Eerdmans Publishing Company, Grand Rapids, MI.

Noll, A.M., 2012, Turning points: Decisive moments in the history of Christianity, Baker Academic, Grand Rapids, MI.

Oberman, H.A., 2004, The reformation roots and ramifications, T\&T Clark International, New York.

Peel, D., 2002, Reforming theology: Explorations in the theological traditions of the United Reformed Church, Healeys Printers, London.

Pillay, J., 2002, The Church and development in the new South Africa, UCT, Cape Town.

Smith, D.J., 2007, Essays in public theology: Collected essays 1, Sun Press, Stellenbosch.

The Accra Confession: Covenanting for Justice in the Economy and the Earth, 2004 viewed 23 August 2017, from https://d3n8a8pro7vhmx.cloudfront.net>Accra

The Belhar Confession - Presbyterian Church (USA), 1986, p. 7, viewed 23 August 2017, from https://www.pcusa.org>uploads>pdfs

Van Beek, H., 2009, Revisioning Christian Unity the Global Christian Forum, Regnum Books International, Great Britain.

West, G.O., 2009, Religion and spirituality in South Africa, Thabo Mbeki's Bible, University of KwaZulu-Natal Press, Pietermaritzburg.

Willis, D. \& Welker, M. (eds.), 1999, Toward the future of reformed theology: Tasks, topics, traditions, William B. Eerdmans Publishing Company, Grand Rapids, MI. 